\title{
Challenges of Acquisition and Retention of Customers in a Competitive Market \\ Dr.Egboro Felix
}

Department of Business Administration and Management,

Delta State Polytechnic, Otefe-Oghara, Delta State, Nigeria.

felixegboro@gmail.com

\begin{abstract}
In a world of ever changing customer expectation, and competitive business environment, building corporative and collaborative relationship with customers seems to be the most prudent way to keep track of their changing expectation and appropriately influencing them. One way in which some companies are developing an improved focus on Customer Relationship Management (CRM), is through the establishment or consideration of splitting the marketing manager's job into two parts: one for acquisition and one for retention. Offensive marketing emphasize on customer acquisition while defensive marketing emphasizes customer retention. The kinds of skills that are needed for people, in acquisition are in the factual aspect of marketing such as advertising, sales while that of retention is on satisfaction, loyalty, customers service, customization, community building and reward program.
\end{abstract}

KEYWORDS: Customer relationship management, customer satisfaction, customer acquisition, customer retention, community building.

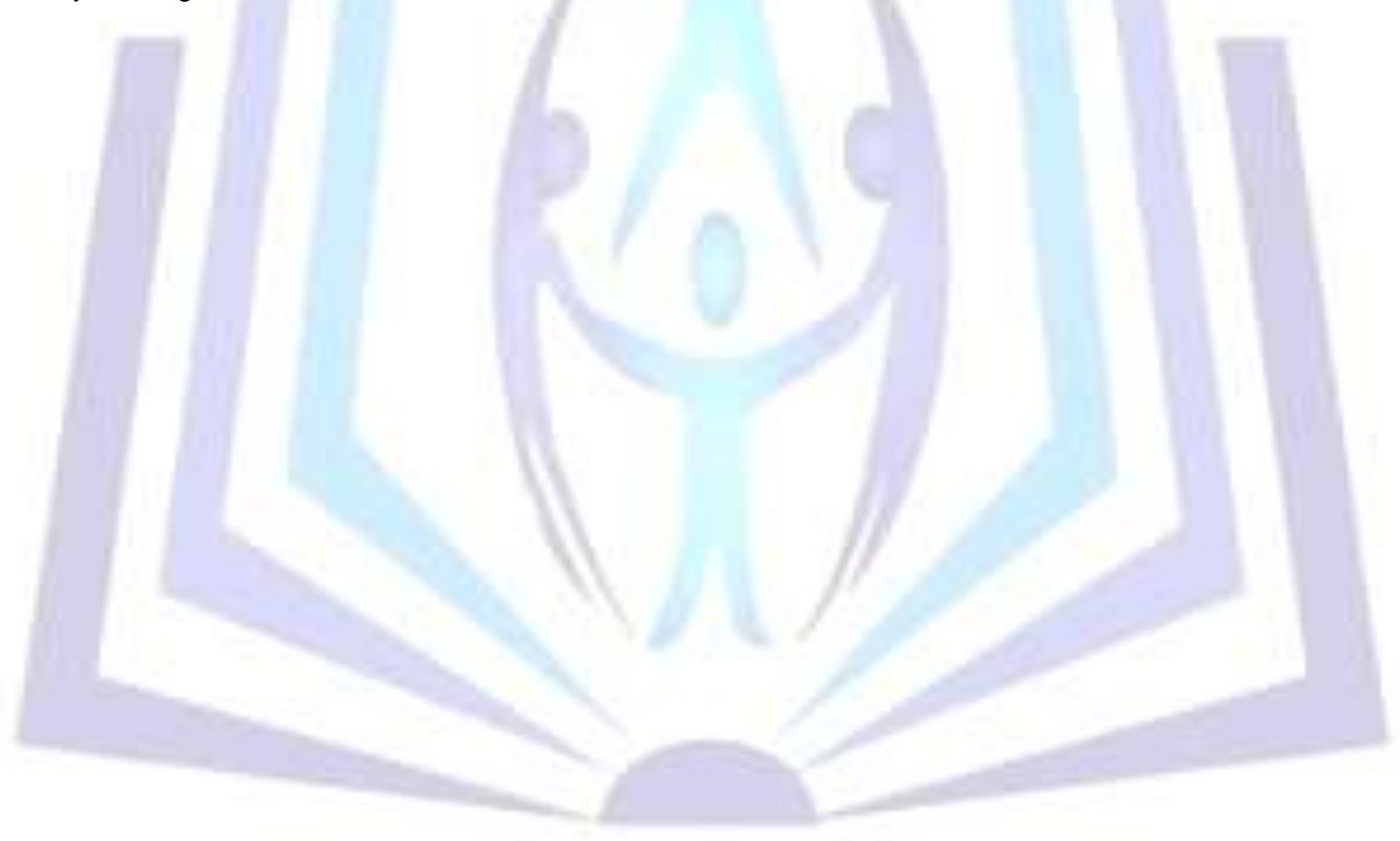

\section{Council for Innovative Research}

Peer Review Research Publishing System

\section{Journal: International Journal Of Management \& Information Technology}

Vol . 10, No 8

editorsijmit@gmail.com

www.ijmit.com 


\section{Introduction}

The concept of acquisition and retention of customers is embedded in Customer Relationship Management (CRM). Marketing is the delivery of customer satisfaction at a profit, (Kotler, 2002). In a simpler form, are those things that are done to attract and retain customer at a profit. This simple definition tells that marketing is basically customer oriented in nature. Measuring customer satisfaction leads to identifying ways to improve product/service quality which in turn leads to increasing the company's competitive advantage.

In order to acquire customers, different tools or strategies are used to obtain information about customers needs, preferences, perception and how to manage their satisfaction. Buying patterns are constantly changing and therefore it is important that dynamic organizations have a range of options when trying to determine the requirements of their customers, thereby acquiring them as real customers.

Acquisition and retention of customers can effectively be achieved through customer relationship management. Shani and Chalasami (1992) defined customer relationship management as an integrated effort to identify, maintain, and build up a network with individual consumers and to continuously strengthen the network for the mutual benefit of both sides, through interactive, individualized and value-added contacts, over a long period of time.

Customer relationship management is a comprehensive strategy and process of acquiring, retaining and partnering with selective customers to create superior value for the company and the customer. It involves the integration of marketing, sales, customer service, and the supply-chain functions of the organization to achieve greater efficiency and effectiveness in delivering customer value. Johnson and Selnes (2004) postulated that customers can be classified into four groups: strangers, acquaintances, friends and partners.

* Strangers are potential customers who have no current relationships with the firm.

* Acquaintances are customers who have low involvement with the firm, can easily switch and are retained based merely on their satisfaction with current offerings.

* $\quad$ Friends base their relationship with the firm on satisfaction and trust.

Partners represent the most committed segment and the offering for them is customized, dedicated resources being devoted to the individual customer. As the level of commitment increases, the value of the offering becomes more customized and thus more difficult to compare to other firms offers.

The main objective of this article is to examine the challenges of acquiring and retaining real customers in a competitive business environment and the strategies or tools to be employed to overcome the challenges.

\section{Statement of the Problem}

Many firms do not employ appropriate criteria to identify profitable customers and their marketing programs are broadly communicated to potential customers who may or may not be profitable. Consequently, customer acquisition can be a costly and risky process, especially because new customers may not represent a good fit for the organization's value propositions.

Customer retention and defection are complex processes. Many firms use Customer Life Time Value (CLV) to allocate resources to customers or customer segments, thus accurate calculations are important. Customer Life Value (CLV) production should based on forecasts of revenue sources and costs to serve, based on a particular set of marketing actions and an environmental scenario, where multiple forecasts are possible. If accurate calculation of customer life time value is not determined, non-productive customers may be targeted.

Consumers are less willing to make compromises of trade-off in product and service quality. The focus of this paper, is to mirrow the challenges of acquisition and retention of consumers in competitive business and how they can be overcome.

\section{Objectives of the Study}

1) To determine the challenges of acquisition and retention of customers.

2) To suggest/proffer solutions to these challenges.

\section{Hypothesis Formulation}

$\mathrm{Ho}_{1}$ : $\quad$ Customers switching pattern does not affect market share.

$\mathrm{Ho}_{2}$ : Quick customer service, product quality, customization, reward program, quick response to customer complaints, does not affect customer retention.

\section{LITERATURE REVIEW}

\section{Customer Acquisition}


Traditionally, marketers have been trained to acquire customers, either new ones who have not bought the product category before or those who are currently competitors' customers. This has required heavy doses of mass advertising and price oriented promotions to customers and channel members.

Today, the tone of the conversation has changed from customer acquisition to retention. This requires a different mindset and new set of tools, however, acquisition dominates retention.

Customer acquisition is a first step in building a customer base. Targeting, acquiring and keeping the right customers entails a consideration of fit with current firm offering, future profitability, and contribution to the overall business risk. Many firms do not employ appropriate criteria to identify profitable customers and their marketing programmes are broadly communicated to potential customers who may or may not be profitable.

Consequently, customer's acquisition can be a costly and risky process because new customers may not represent a good fit for the organization's value propositions. Customer - product fit becomes important because campaigns aimed toward new customers that change the positioning of a product can alienate existing customers, (Mittal and Kamakura, 2001).

Lack of focus during acquisition activities is very likely to result in adverse selection, whereby the prospects that are least likely to be profitable, are mostly likely to respond to marketing efforts. The problem is particularly worrisome in credit companies because they must verify the suitability of all respondents, thus incurring screening costs, (Cao and Gruce, 2005). Data from a firm's CRM system to target prospects that are likely to respond must be screened and approved. This approach increases the number of customers who are approved while reducing the number of "bad" customers.

Mass marketing approaches such as television, ratio or print advertising are useful generating awareness and achieving other communications objectives but they are poorly suited for customer acquisition due to their impersonal nature. More conventional approaches for targeting customers include a portfolio of direct marketing methods such as telemarketing, direct mail and direct sales, when the nature of the product is suitable.

An extremely popular form of internet - based direct marketing is the use of personalized e-mails. Direct e-mail has become a very popular and effective method for targeting current and potential customers.

\section{Challenges:}

Lack of focus during acquisition activities is likely to result in adverse selection whereby the prospects that are least likely to be profitable are mostly likely to respond to marketing efforts. Cao and Gruca (2005) address the problem of adverse selection by using data from a firm's CRM system to target prospects likely to respond and be approved. This approach increase the number of customers who are approved while reducing the number of "bad" customers. Seeking historical data for new customer is a big challenge.

Another challenge is the determination of lifetime customer value or LCV which is used through the data base to predict current and future profitability to the firm. When a profit figure can be assigned to each customer, the marketing manager can then decide which customer to target. The past profit that a customer has produced for the firm is the sum of the margins of all products purchased over time less the cost of reaching that customer.

LCV is calculated by adding forecasts for the major parameters and discounting back. This obviously requires assumption about future purchasing, product and marketing costs, as well as how long the customer can be expected to remain with the firm. The LCV is used to reduce product marginal costs, reduce customer acquisition costs.

If individual customer - based profitability is available through LCV or similar analysis, it would seem to be a simple task to determine which customer to focus. The goal is to use the customer profitability analysis to separate customers that will provide the most long-term profits from those that are currently hurting profit.

\section{Customer Retention}

Marketers have always been preoccupied with defensive strategies aimed at increasing customer retention, thereby increasing revenues and profitability, (Fornell and Wernerfelt, 1987).

"How long on average, do customer remain with the company? This is a big question marketing managers often ask themselves". The Customer Life Value (CLV) explained under customer acquisition is strongly referred to as equivalent to the management of customer retention, (Bolton, 1998).

In the management of customer retention, there are five basic activities or components that are indispensable.

1. A database of customer activity

2. Analyses of the database

3. Based on the analyses, decision about which customers to target

4. Tools for targeting the customers

5. How to build relationships with the targeted customer, (Russell, 2001).

Another comprehensive set of relationship programs that enhance customer retention include

* Customer service

* Frequency/loyalty programs 
Customization

Reward programs

Community building (Russel, 2001)

Due to the competitive nature of today business environment, targeted customers are most valuable to the company. Programs designed to enhance customer service are normally two types - reactive and proactive services.

1. Reactive service is where the customer has a problem e.g. (product failure, question about a bill, product return) and contacts the company to solve it.

2. Proactive service is a situation where the manager has decided not to wait for customers to contact the firms but to rather be aggressive in establishing a dialogue with customers prior to complaining or other behaviour sparking a reactive solution. This is more a matter of good account management where the sales force or other people dealing with specific customers are trained to reach out and anticipate customers' needs.

Loyalty/frequency programs provide rewards to customers for repeat purchasing. These programs are expensive. The big question in this program is whether loyalty is being increased or is spending behaviour that is being increased.

Through this program, it is difficult to gain competitive advantage. However, loyalty programs can be very successful by increasing customer switching cost and building barriers to entry, (Rusell, 2001).

Customization implies the creation of products and services for individual customers, not simply communicating to them, (Rusell, 2001). Some companies developed processes and systems for creating customized products according to customers' tastes, whereby customers take a list of product attributes and determine which they want. The idea is that it has turned customers into product makers rather than simply product takers.

Communities are networks and relationships. One of the major uses of the web for both online and offline businesses is to build a network of customers for exchanging product - related information and to create relationships between the customers and the company or brand. These networks and relationship are called communities. The goal is to take a prospective relationship with a product and turn it into something more personal. Consequently, the manager can build an environment which makes it more difficult for the customer to leave the "family" of other people who also purchase from the company. In the software company, Adobe builds community by devoting a section of its web sites to users and developers. By giving the customers the impression that they own this section of the site and being open to the community about production information Adobe creates a more personal relationship with its customers.

\section{Customer Defection}

Customers engage in switching patterns from one brand of a company product to another. This customer defection or switching pattern can reduce a company market share and increase another company market share in an industry.

Market models are used to determine the eventual market share of a product and is widely used to examine and in predicting the behaviour of consumer in terms of their brand loyalty and their switching patterns from one brand to other brands, (Banga, 2008). Without considering customer's migratory behaviour, customers will be undervalued since they are considered lost when they switch to competition and they are accounted for as new customers when they switch back, (Rust et al 2004).

\section{Customer Divestment}

Retrenchment is usually accomplished by diverting businesses or customers that have little or no strategic fit with the businesses that management wants to concentrate on, or that are too small to make a sizable contribution to earnings.

Divesting such businesses or customers free resources can be used to reduce debt to support expansion of the remaining businesses or to make acquisition that materially strengthen the company's competitive position, (Thompson and Strickland, 2001).

However, Bolton (1998) opined that although organization may have customers who are unprofitable to serve, finding customers or refusing to serve them is seldom necessary. Alternatively, organization can offer a less attractive value proposition to some segments by raising prices or offering lower product quality. In addition, marketing campaigns can be designed to attract profitable customers and be unappealing to less desirable customers. Another position is to find a way to make the latter group profitable by changing the firm's business model.

\section{Customer Satisfaction and Customer Retention}

Customer satisfaction can refer to different areas of the relationship with the customer, including satisfaction with the quality of a product or service, satisfaction with an ongoing business relationship, satisfaction with the price/performance ratio of a product or service, or satisfaction because a product/service met a customer's expectation, (Broetzmann et al, 1995).

Customer satisfaction has been defined as the result achieved when service or product features respond to customer needs and when the company meets or exceeds customers' expectation over the life time of a product or service, (Kelsey and Bond, 2001). Satisfaction is the customer's fulfillment response. It is a judgment that a 
product or service feature, or the product or service, itself, provided (or is providing) a pleasurable level of consumption - related fulfillment, including levels of under - or - over - fulfillment (Oliver, 1997).

There is considerable evidence to support the view that customer satisfaction is vital to customer retention and to the success of the organization and profitability, (Hesket et al, 1994).

Rossomme (2003), pointed out that customer satisfaction measurement is the principal tool by which organizations assess the health of their relationship with their customers. A customer satisfaction programme provides the ability to diagnose and strengthen relationships with "at risk" customers - those clients with negative service experience, new customers, and customers in competitive markets, (Hesket et al, 1994).

Measuring satisfaction must be a continuous process that infuses the voice of the customer into the firm's decision process, (Nauman et al, 2001). They believed that there are three reasons for this.

Firstly, very few firms ever achieve $100 \%$ customer satisfaction but by striving for it, a company will continuously improve and so will employee morale and satisfaction.

Secondly, because customers' views are constantly changing, if a customer satisfaction programme fails to infuse the voice of the customer, they may defect or may drift away.

The third reason involves competition. If a firm is not engaging in competitive benchmarking on a continual basis, competition may over take it. The firm may be improving but at a slower rate than its competitors. The results will be competitive vulnerability followed by poorer financial performance.

In fact, a customer satisfaction programme is a comprehensive system approach to effectively managing customer needs and experience. It involves systematically listening to multiple customer voices, analyzing prioritizing and responding to customer issues for the acquisition and retention of customers.

\section{Customer Complaints}

Today, gathering customer complaints is a standard practice for most companies. Research has shown that effectively handling customer complaints has dramatic impact on customer retention and loyalty, (Singh and Wikes, 1996).

The biggest challenge is that only a small percentage of dissatisfied customers actually complain. Blodget et al, (1995) suggested that service providers should encourage customers who are dissatisfied to complain and seek redress, so that the firm has a chance to remedy the problems and retain those customers.

Garver (2003) believed that relationship and transaction surveys along with customer complaint data are the cornerstone of any systematic programme designed to listen to customers. Sander and Brombecher (2000) define five aspects that can lead to formal customer complaints.

1. The product is not safe.

2. The product does not work.

3. The product does not comply with specifications.

4. The product does not meet customer expectations.

5. The product does not have sufficient satisfying aspects.

\section{Competition and Customer Retention}

The number of sellers of a products in a market determine the nature and degree of competition in the market, (Dividi, 2005). Porter, (1998) stated that competitive strategy is about being different. It means deliberating choosing to perform activities than rivals, to deliver a unique mix of value. Organization succeed in a competitive market place over the long run because they can produce better product or service or can do certain things their customers value better than their competitors, (Jobber, 2004).

Generally, competitive focuses on price, product quality, product reliability, product features, product performance, quick services, convenience or brand repetition (Porter, 1998).

In some industries competition focus on who has the best price, while in others competition is centered on quality and reliability or product features and performance or quick service and convenience or brand reputation.

In other industries, the challenge is for companies to work cooperatively with suppliers, customers, and may even select competitors to create the next round of product innovations and open up whole new vistas of market opportunities, (Thompson and Strickland, 2001).

Kotler, (2004) stated that nothing focuses the mind of a marketing manager better than the constant sight of a competitor who wants to wipe him off the map. He emphasized that the real question in industry completion is not how well a firm is doing today against its own history but how it is doing against her competitors.

An industry key success factors for competition addresses three questions.

* On what basis do customers choose between the competing brands of sellers?

What product attributes are crucial?

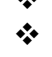

What resources and competitive capabilities does a seller need to have to be competitively successful?

Competitive advantage is secured through intelligent identification and satisfaction of customers needs better and sooner than competitors and sustenance of customer's satisfaction through better customer service tool.

Thompson and Strickland (2001) stated that some main strategies of retaining customers is that a defender can introduce new features, add new models or broaden its product line. A defender can also hire talented employees to broaden or deepen the company's base of core competencies or capabilities in key areas, so as to be able to overpower rivals that attempt to imitate its skills and resources. It can try to discourage brands by lengthening warranty coverage, offering free training and support services developing the capability to deliver products to users faster than rivals can, providing coupons and sample giveaways to buyers and making early announcements about impending new products or price changes to induce potential buyers to postpone switching, (Thompson and Strikland, 2001). 
It can grant dealers and distributors' volume discount or better financing terms to discourage them from experimenting with other suppliers or it can convince them to handle its product line exclusively.

In a way of summary, differentiation strategies seek to produce competitive edge that leads to customer retention, by incorporating attributes and features into a company's product/service offering that rivals do not have. Anything a firm can do to create customer value represents a potential basis for differentiation. Successful differention is usually keyed to lowering the customers cost of using the item, raising the performance the customer gets, or boosting a customer's psychological satisfactions.

\section{Methodology}

The study employed survey design and ex-post facto research design in determining the effects of consumers switching pattern (defection) on market share. The switching pattern of customers from the roofing sheet product companies in Delta State Nigeria, who bought 1000 pieces of two brands was used to justify the effect of consumers switching pattern on market share. The Markov Chain model was used to determine this cause / effect relationship.

Markov models are used to determine the eventual market share of a product and is widely used to examine and in predicting the behaviour of consumers in terms of their brand loyalty and their switching patterns from one brand to other brands, (Banga, 2008).

The multiple regression statistical technique was also used to determine the extent to which quick customer service, product quality, customization, reward programs and quick response to complaints affects customer retention, using 136 staff from two roofing sheets companies in Delta State, Nigeria.

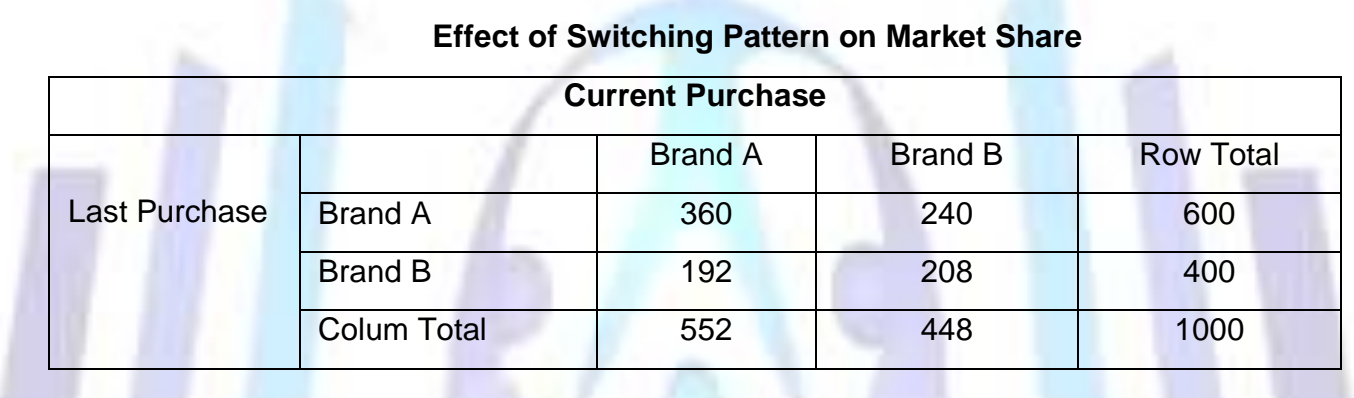

In a market survey, it was found that out of 600 customers who had purchased Brand $A$ of roofing sheet product, only 360 returned to buy the Brand $A$, the remaining 240 switched or defected to Brand $B$.

Also, out of 400 customers who had formerly purchased Brand B of the roofing sheets products only 208 had a repeat purchase, the remaining 192 defected or switched to Brand A.

Step I: Conversion to transition matrix

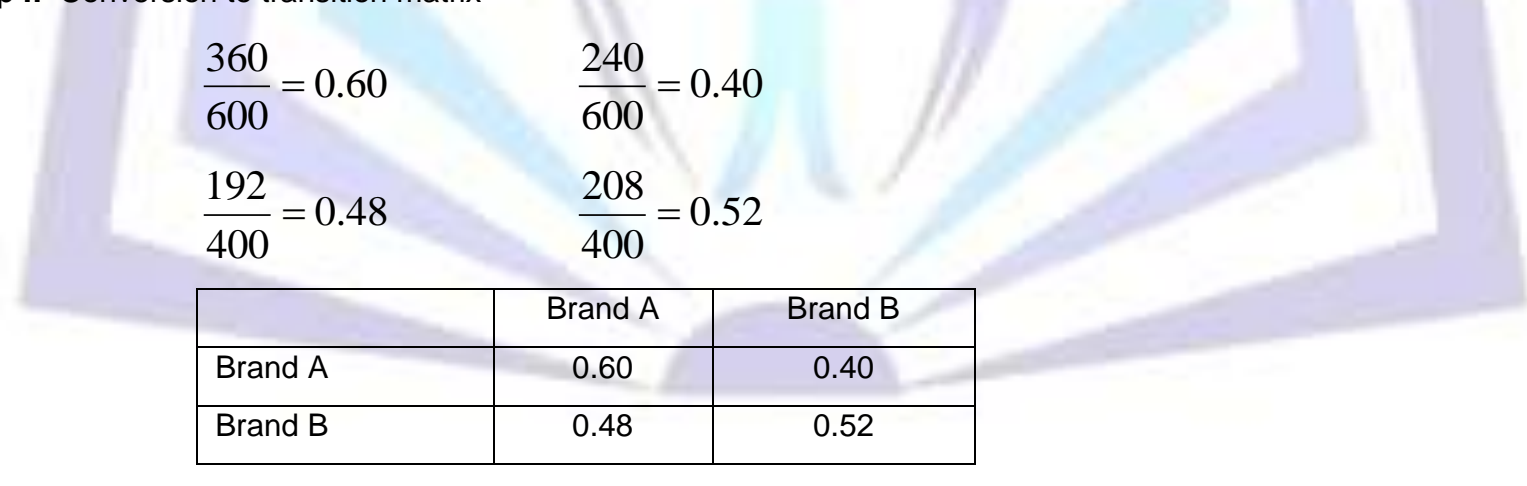

Step II: Use simultaneous equation to determine the ratio of each brand, and consequently the market share of each brand.

Let ' $a$ ' and ' $b$ ' be the respective share of brand $A$ and brand $B$

Then

$$
\begin{aligned}
& a+b=1 \\
& a=0.60 a+0.48 b \\
& b=0.40 a+0.52 b
\end{aligned}
$$

Since

$$
a+b=1
$$$$
1-b=a
$$

Thus

$$
1-b=a=0.60 a+0.48 b
$$




$$
\begin{aligned}
1-b & =0.60 a+48 b \\
1 & =0.60 a+1.48 b
\end{aligned}
$$

$1-a=b=0.40 a+0.52 b$

$1-a=0.40 a+0.52 b$

$1=1.40 a+0.52 b$

Thus

$$
0.6 \mathrm{a}+1.48=1
$$$$
1.40 a+0.52 b=1
$$

Since

$$
\text { equ } 1 \text { and } 2 \text { is equal to } 1
$$

$$
0.6 a+1.48 b=1.40 a+0.52 b
$$

Collect like terms

$$
\begin{gathered}
1.48 b-0.52 b=1.40 a-0.6 a \\
0.96 b=0.80 a
\end{gathered}
$$

The sum of the ratio of the two brands is $0.96+0.80=1.76$

Step III: Determine the market share of each brand using the ratio of each brand.

1. For brand A market share $=\frac{0.96}{1.76} \times 10054.5 \%$

2. For brand B market share $=\frac{0.80}{1.76} \times 100=45.5 \%$

From the analysis above, brand A has a higher market share of $54.5 \%$ while brand $B$ has $45.5 \%$ market share. This position is due to the switching pattern of the consumers.

The Effect of quick customer service, product quality, customization, reward program and quick response to customers' complaints

The multiple regression shows that quick customer service $(p=026<0.05)$, product quality $(p=002<0.05)$ and quick response to customers complaints $(p=003<0.05)$ easily lead to customers retention respectively. Customization and reward system $(p=520>0.05)$ and $(p=099>0.05)$ does not quickly lead to customer retention. (See Appendix I)

\section{CONCLUSION}

It is one thing to bear children, it is another to nurture them to old age and enjoy the fruit of your labour. It is painful to lose children to Satan the enemy, due to lack of commitment to the upbringing of the children.

Competitors are business enemies who would want to wipe others from the industry, (Kolter 2009).

It becomes imperative that marketers acquire and use good marketing strategies or tools to retain their customers. A loss of customer to competitors enlarges competitors' market shares. Strategies of customer retention among others include product performance quality, product reliability, on time delivery, continuous improvement, product durability, fast delivery, low cost of production, product customization, after sales service, innovation in manufacturing process, attending to customers complaints, low product defect rate, customer knowledge management, customer problem solving skills, dependable promises, ability to rapidly change production volume, design adjustment, broad product line, reward programs, community building.

\section{RECOMMENDATIONS}

1. In order to retain customers in a competitive market, marketers' attention must be focused mostly on quick customer service, quality product and quick response to customers complaints as a means of customer satisfaction.

2. There should be proper customer relationship management by tracking customer database to determine the rate of customer defection or switching to competitors products. This reduces company's market shares.

3. There should be more of proactive service than reactive service in order to solve customers' problems before they occur. There should be constant customer after sales service.

\section{REFERENCES}

1. Banga, T. R. (2008). Industrial Production and Management. Delhi, Khanna Publishers.

2. Bolton, R. N. (1998). "A Dynamic Model of the Duration of the Customers Relationship with a Continuous Service Provider: "The Role of Satisfaction" Marketing Science, 17(1), $45-65$.

3. Blodgett, J. G., Wakefield, K. L. and Barnes, J. N. (1995). 'The Effects of Customer Service on Consumer Complaining Behaviour'. Journal Service Industry Management, Vol. 9 PP. $31-42$. 
4. Broetzmann, S. M., Kemp, J., Rossano, M. and Marwah, J. (1995). 'Customer Satisfaction - Lip Service or Management Tool? Managing Service Quality, Vol. 5, No. 2, pp. 13 - 18.

5. Cao, Y. and Gruca, T. S. (2005). "Reducing Adverse Selection through Customer Relationship Management". Journal of Marketing, 69(4) 219-229.

6. Divide, D. N. (2005). Managerial Economics. New Delhi, Vikas Publishers.

7. Garver, M. S. (2003). "Listening to Customers". Mid-American Journal of Business, Vol. 16, No 2, PP. 41 - 54

8. Heskett, J. L., James, T. O., Loveman, G. W., Sasser, W. E. and Schlesinger, L. A. (1994). 'Putting the ServiceProfit Chain to Work'. Harvard Business Review, Vol. 72, No 2, PP 164 - 174.

9. Jobber, D. (2004). Principles and Practice of Marketing. England, McGraw Hill Publishers.

10. Johnson, M. D. and Selnes, F. (2004). 'Customer Portfolio Management: Toward on Dynamic Theory of Exchange Relationships". Journal of Marketing, 68 (4) 1 - 17.

11. Kelsey, K. D. and Bond, J. A. (2001). 'A Model for Measuring Customer Satisfaction within an Academic Centre of Excellence'. Managing Service Quality, Vol. 11, No 5.

12. Kotler, P. (2002). Marketing Management. New Jersey, Prentice Hall.

13. Mittal, V. and Kamakura, P. (2001). "Attribute Performance and Customer Satisfaction Over Time. Journal of Service Marketing, Vol. 15, No. 5 pp $343-356$.

14. Nauman, E., Jackson, D. W. and Rosenbaum, M. S. (2001). 'How to Implement a Customer Satisfaction Program'. Business Horizons, Vol. 44, No. 1 pp $39-40$.

15. Oliver, R. L. (1997). Satisfaction: A Behavioural Perspective on the Consumer. New York, McGraw Hill.

16. Porter, M. E. (1998). Competitive Advantage. New York, Free Press.

17. Rossomme, J. (2003). 'Customer Satisfaction Measurement in a Business - to - Business Context: A Conceptual Framework'. Journal of Business and Industrial Marketing, Vol. 18, No. 2, pp. 179 - 195.

18. Russell, S. W. (2001). A Framework for Customer Relationship Management. Journal of Marketing, 59(11) $45-$ 50 .

19. Rust, R. and Zahorik, A. (2004). Customer Satisfaction, Customer Retention and Market Share. Journal of Retaining, 69(2) $193-215$.

20. Sander, J. and Brombacher, A. C. (2000). 'Reliability by Design Techniques for Electronics Components and System'. New York, John Wiley and Sons.

21. Shani, D. and Chalsani, S. (1992). "Exploiting Niches using Relationship Marketing". Journal of Consumer marketing, 9(3) $33-42$.

22. Sign, J. and Wilkes, R. E. (1996). 'When Consumers Complain: A path Analysis of the Key Antecedents of Customer Complaint Response Estimates'. Journal of Marketing Research, Vol. 36, pp. 356 - 372.

23. Thompson, A. A. and Strickland, A. J. (2001). Strategic Management, Concepts and Cases. New Delhi, McGraw Hill.

\section{Appendix}

\section{Multiple Regression Results}

Descriptive Statistics

\begin{tabular}{|l|c|c|c|}
\hline & Mean & Std. Deviation & $\mathrm{N}$ \\
\hline Retention & 2.7130 & .55864 & 136 \\
\hline Quick customer service & 1.7758 & .53837 & 136 \\
\hline Product quality & 1.9375 & .36208 & 136 \\
\hline Customization & 2.1349 & .19526 & 136 \\
\hline Reward program & 2.0625 & .43353 & 136 \\
\hline Quick response to complaints & 2.2854 & .44261 & 136 \\
\hline
\end{tabular}

Model Summary

\begin{tabular}{|l|l|l|l|c|c|}
\hline Model & $\mathrm{R}$ & $\mathrm{R}$ Square & Adjusted R Square & $\begin{array}{c}\text { Std. Error of the } \\
\text { Estimate }\end{array}$ & $\begin{array}{c}\text { Durbin- } \\
\text { Watson }\end{array}$ \\
\hline
\end{tabular}




\begin{tabular}{|l|l|l|l|l|l|}
\hline 1 & $.778^{\mathrm{a}}$ & .606 & .540 & .37880 & 1.901 \\
\hline
\end{tabular}

a. Predictors: (Constant) quick customer services, product quality, customization, reward system, quick response to customer complaints.

b. Dependent Variable: Customer retention

\section{ANOVA $^{\text {b }}$}

\begin{tabular}{|l|c|c|c|c|c|}
\hline Model & Sum of Square & $\mathrm{df}$ & Mean Square & $\mathrm{F}$ & Sig. \\
\hline 1 Regression & 6.618 & 5 & 1.324 & 9.224 & $.000^{\mathrm{a}}$ \\
\hline Residual & 4.305 & 30 & .143 & & \\
\hline Total & 10.923 & 35 & & & \\
\hline
\end{tabular}

a. Predictors: (Constant) quick customer services, product quality, customization, reward system, quick response to customer complaints.

b. Dependent Variable: Customer retention

\section{Coefficients $^{a}$}

\begin{tabular}{|c|c|c|c|c|c|}
\hline \multirow{2}{*}{ Model } & \multicolumn{2}{|c|}{ Unstandardized Coefficients } & $\begin{array}{c}\text { Standardized } \\
\text { Coefficients }\end{array}$ & \multirow{2}{*}{$t$} & \multirow{2}{*}{ Sig. } \\
\hline & $B$ & Std. Error & Beta & & \\
\hline 1 (Constant) & 4.400 & 992 & & 4.436 & .000 \\
\hline Quick services & .338 & .144 & .325 & 2.339 & .026 \\
\hline Product quality & -.631 & .189 & -.409 & -3.342 & .002 \\
\hline Customization & -.223 & .342 & -.078 & -.651 & .520 \\
\hline Reward program & .295 & .173 & .229 & 1.703 & .099 \\
\hline $\begin{array}{l}\text { quick response to } \\
\text { complaints }\end{array}$ & -.523 & 161 & -.415 & -3.246 & .003 \\
\hline
\end{tabular}

a. Dependent Variable: Customer retention 